\title{
Pengembangan Sistem Pengumpulan Data Imunisasi Terpadu Elektronik untuk Mendukung Evaluasi Program Imunisasi Di Dinas Kesehatan Kabupaten Brebes
}

\author{
Lina Khasanah*, Aris Puji Widodo**, Farid Agushybana*** \\ *Politeknik Kesehatan Kementrian Kesehatan Tasikmalay, Cirebon \\ ** Fakultas Sains dan Matematika, Universitas Diponegoro, Semarang \\ *** Fakultas Kesehatan Masyarakat, Universitas Diponegoro, Semarang \\ Email :linaelshirazy@gmail.com
}

\section{ABSTRACT}

The immunization program includes planning, implementing, monitoring and evaluating immunization activities. The current immunization data recording system has not been able to produce complete, relevant, timely, accessible and easily understood information and has not provided information that can describe immunization coverage in the form of geographical distribution in each region according to the needs of the leadership. To develop an integrated electronic immunization data collection system model to support the evaluation of immunization programs. This type of research is a research action in the form of system development using the FAST method (framework for the application of systems techniques), with subjects from 3 Health Offices and 2 Puskesmas. System evaluation uses the Post study system usability questioner (PSSUQ) to measure usability in the system developed, tested on 20 Puskesmas staff. The resulting system is an integrated electronic immunization data collection system which includes routine immunization coverage, BIAS (School Children Immunization Month) and Vaccine Stock which is able to cover program reporting needs and evaluation of immunization programs through regional mapping. The results of system tests show that the system developed is in the category of "Eligible" to use. The data collection system includes routine immunization coverage, BIAS and vaccine stock. This system is very helpful for immunization programs in carrying out program reporting and evaluation, especially for more interpretative immunization coverage reports in the form of mapping the area to the village level.

Keywords : Information System; Immunization; Geographic Information Systems, PSSUQ

\section{PENDAHULUAN}

Program imunisasi merupakan program prioritas pemerintah. Menurut Kementerian Kesehatan Republik Indonesia, penyelenggaraan program imunisasi mencakup perencanaan, pelaksanaan, monitoring dan evaluasi kegiatan imunisasi. ${ }^{1}$ Pelayanan imunisasi memiliki tujuan jangka pendek yaitu mencegah terjadinya penyakit tertentu pada seseorang dan menghilangkan penyakit tertentu pada sekelompok masyarakat serta diharapkan ke 
depan dapat mengeliminasi suatu penyakit. ${ }^{2}$

Perencanaan sebagai salah satu fungsi pengelolaan, merupakan kegiatan yang sangat penting karena dengan perencanaan, tujuan program imunisasi diharapkan dapat tercapai dengan menggunakan sumber daya dan sumber dana secara efektif dan efisien. Oleh karena itu, informasi perencanaan yang dapat mendukung tercapainya tujuan program imunisasi secara efektif dan efisien tersebut sangat diperlukan oleh unit pelaksana.

Dinas Kesehatan Kabupaten Brebes merupakan unit pelaksana daerah yang bertugas dalam bidang kesehatan. Program imunisasi terdiri dari imunisasi tak rutin dan imunisasi rutin. Berdasarkan hasil susenas 2017, bahwa angka cakupan Balita yang imunisasi BCG 88,24\% dan yang mendapatkan imunisasi lengkap sebesar 52,52\%. ${ }^{3}$ Angka cakupan imunisasi ini masih belum memenuhi target capaian program imunisasi. Salah satu cara dalam upaya peningkatan kualitas informasi imunisasi adalah memanfaatkan perkembangan sistem informasi berbasis teknologi. Sistem informasi imunisasi telah direkomendasikan sebagai salah satu strategi dalam meningkatkan angka cakupan imunisasi dan penurunan kasus PD3I. ${ }^{4}$ Menurut hasil penelitian yang telah dilakukan Willis bahwa menggunakan Sistem Informasi Geografis (SIG) dapat membantu memberikan informasi kepada masyarakat tentang keberadaan fasilitas pelayanan kesehatan yang ada di Magelang. ${ }^{5}$

Dari hasil studi pendahuluan dan analisa terhadap sistem yang sekarang berjalan terdapat beberapa temuan masalah dan kelemahan dalam sistem informasi untuk mendukung evaluasi program imunisasi. Tujuan dari evaluasi yaitu untuk mengetahui hasil ataupun proses kegiatan bila dibandingkan dengan target atau yang diharapkan. Beberapa macam kegiatan evaluasi dilakukan secara berkala dalam imunisasi. ${ }^{1,6}$

Evaluasi program imunisasi dapat dilakukan dengan mengumpulkan angkaangka dari Puskesmas yang kemudian di analisis hasilnya. Analisis yang baik dapat dilakukan apabila hasil dari penyajian informasi yang disajikan sangat representatif untuk proses evaluasi program itu sendiri. Beberapa hal yang dilihat pada evaluasi program imunisasi adalah stok vaksin, angka cakupan imunisasi per bulan maupun per tahun (imunisasi rutin dan BIAS) serta indeks pemakaian vaksin. ${ }^{1}$

Data yang sekarang ada belum bisa memfasilitasi para pembuat kebijakan di bidang kesehatan dalam pengambilan keputusan. Karena keterbatasan atau ketersediaan data dan informasi yang akurat, tepat dan cepat. Data dan informasi merupakan sumber daya yang sangat strategis dalam pengelolaan pembangunan kesehatan, yaitu pada proses manajemen, pengambilan keputusan, kepemerintahan dan penerapan akuntabilitas. ${ }^{7}$

Penerapan teknologi informasi pada pengelolaan data kesehatan memerlukan perhatian dan kerangka konseptual secara menyeluruh. Hal ini sangat penting dalam rangka pelaksanaan Health Information Technology. ${ }^{8}$ Meningkatnya penggunaan teknologi informasi menuntut keakuratan data, kualitas dan produk informasi yang sesuai dengan kebutuhan di lingkup pelayanan kesehatan sehingga menjadikan sistem informasi kesehatan yang lebih baik.

Teknologi yang digunakan dalam sistem informasi saat ini adalah kombinasi antara manual dan pemanfaatan komputer secara terbatas. Hal ini menyulitkan petugas pengolah data dalam mengolah dan menyajikan secara cepat data dan informasi 
yang dibutuhkan. Informasi yang dihasilkan dari sistem imunisasi yang ada belum bisa memenuhi kebutuhan informasi para pimpinan dan belum mencakup sebaran geografis untuk kebutuhan analisis evaluasi program imunisasi sampai tingkat desa.

Berdasarkan penjabaran di atas, penelitian ini bertujuan mengembangkan sistem pengumpulan data imunisasi terpadu elektronik untuk menghasilkan penyajian informasi yang mudah diinterpretasikan, tepat waktu dan dapat mendukung evaluasi program imunisasi berupa sebaran cakupan imunisasi sampai tingkat desa.

\section{METODE PENELITIAN}

Jenis penelitian ini actions research berupa pengembangan sistem (system development). Penelitian pengembangan sistem dapat dikatakan menyusun sistem baru untuk menggantikan sistem yang lama secara keseluruhan atau memperbaiki sistem yang telah ada. ${ }^{9}$

Pada proses pengembangan sistem menggunakan metodologi tahapan FAST (Framework for application of system tehnique). Tahapan FAST meliputi studi pendahuluan, analisis masalah, analisis kebutuhan, analisis keputusan, tahap perancangan sistem, tahap pembangunan sistem, tahap penerapan/ujicoba sistem dan evaluasi sistem. ${ }^{11,12}$

Pada tahapan FAST melalui penggalian informasi dengan wawancara mendalam dan observasi, mengumpulkan data tentang kebutuhan stake holder mengenai rancangan sistem informasi imunisasi yang sesuai dan menjawab masalah atau merupakan salah satu solusi untuk memperbaiki pelaporan data.

Wawancara mendalam dilakukan kepada subyek penelitian yang terdiri dari 1 orang Kasie Surveilans dan Imunisasi, 1 orang pengelola data program imunisasi di
Dinas Kesehatan, 1 orang staf manajemen dan informasi dan 2 orang pengolah data imunisasi di Puskesmas. Dari hasil penggalian informasi didapatkan kebutuhan output, desain antarmuka, basis data, Entity Relationship Diagram (ERD) dan format penyajian laporan.

Evaluasi sistem dilakukan dengan menggunakan metode kuantitatif melalui serangkaian kuesioner pengukuran usability yang menilai sejauh mana user dapat belajar dan menggunakan suatu produk untuk mencapai tujuannya dan sejauhmana kepuasan user dalam menggunakan produk tersebut. ${ }^{12}$ Metode usablity yang digunakan adalah metode PSSUQ. Subyek pada penelitian ujicoba sistem yaitu petugas pengolah data imunisasi di 20 Puskesmas. PPSUQ merupakan instrumen penelitian yang dikembangkan untuk digunakan dalam evaluasi usability di IBM. PSSUQ digunakan untuk menilai kepuasan pengguna berdasarkan aspek usability dengan mengelompokkan menjadi empat kategori yaitu, system usefullnes (SysUse), information quality (InfoQual), interface quality (InterQual), Overall satisfaction (OverAll). ${ }^{13,14}$

Untuk mengukur tingkat persetujuan user terhadap item-item kuesioner digunakan bentuk score tujuh poin dengan model skala Likert. Pengolahan data dari kuesioner dengan jenis pertanyaan tertutup diolah menjadi data kuantitatif menggunakan skala likert untuk memperhitungkan skor yang dikonversi ke dalam pernyataan predikat. Konversi persentase tersebut dilakukan penyesuaian interpretasi Likert ke pernyataan, terdapat 5 kategori untuk kategori Sangat layak 81\%$100 \%$, kategori Layak 61\%-80\%, kategori cukup layak 41\%-60\%, kategori tidak layak $21 \%-40 \%$ dan kategori sangat tidak layak 
$0 \%-20 \%{ }^{15}$

\section{HASIL PENELITIAN DAN PEMBAHASAN}

Pada penelitian ini, pengembangan sistem yang berarti menyusun suatu sistem yang baru untuk menggantikan yang lama secara keseluruhan atau memperbaiki sistem yang sudah ada. Hal-hal yang menyebabkan perlunya perbaikan sistem yang lama yaitu: 1) munculnya masalah pada sistem yang lama; 2) memanfaatkan kesempatan; 3) adanya instruksi dari pimpinan. ${ }^{9}$ Metode FAST ini meliputi 8 tahapan yaitu :

\section{Studi Pendahuluan}

Tahapan ini merupakan tahapan penggalian masalah yang berhubungan dengan prosedur, formulir dan laporan yang melatarbelakangi pengembangan sistem. Dari hasil wawancara mendalam didapat masalah yang terkait dengan pencatatan dan pelaporan imunisasi, diantaranya 1) pengelola data puskesmas harus menyalin berkali-kali pelaporan baik untuk pelaporan Puskesmas maupun pelaporan ke Dinas Kesehatan, 2) informasi yang dihasilkan hanya dalam bentuk tabel sehingga belum memenuhi kebutuhan data dan informasi ditingkat pimpinan, 3) keterlambatan pelaporan ke Dinas Kesehatan.

Peluang yang menjadi dasar untuk dilakukannya penelitian pengembangan sistem informasi imunisasi adanya kebutuhan untuk membangun sebuah sistem yang dapat meringankan pekerjaan dan bisa mempercepat proses pengolahan data dari banyak puskesmas di tingkat Dinas Kesehatan. Tersedianya sarana dan prasarana baik di Puskesmas maupun di Dinas Kesehatan Brebes untuk mendukung upaya pengembangan sistem informasi dan imunisasi.

Ada tiga hal yang berkaitan dengan penerapan teknologi informasi berbasis komputer yaitu perangkat keras, perangkat lunak dan pengguna. Dalam hal ini sarana dan prasarana termasuk dalam kategori hardware yang keberadaannya mendukung pemanfaatan teknologi informasi. Ketiga elemen di atas saling berinteraksi dan dihubungkan dengan suatu perangkat masukan keluaran (input-output media), yang sesuai dengan fungsinya masingmasing. Perangkat keras adalah media yang digunakan untuk memproses informasi. ${ }^{16}$

Ruang lingkup penelitian dapat dirinci untuk menentukan seberapa besar pengembangan sistem dan menentukan batas-batas dari sistem yang akan dikembangkan. Dari hasil wawancara dan observasi didapatkan bahwa ruang lingkup sistem mencakup pengembangan sistem informasi imunisasi rutin, BIAS dan stok vaksin yang dapat menghasilkan output berupa informasi yang dihasilkan sistem berupa tabel, grafik dan peta terhadap cakupan imunisasi dan dalam bentuk tabel untuk BIAS dan stok vaksin.

Pada kelayakan teknis yang dilihat adalah ketersediaan teknologi. Berdasarkan wawancara dan observasi terdapat fasilitas yang mendukung untuk dikembangkannya sistem informasi yaitu berupa laptop, CPU, printer dan server. Selain itu studi kelayakan pada ketersediaan tenaga yang mengoperasikan, dijelaskan dari hasil wawancara bahwa petugas pengolah data imunisasi memiliki petugas tersendiri untuk setiap Puskesmas, sehingga petugas sudah terbiasa melakukan input dan mengolah data untuk pelaporan program imunisasi.

Kebiasaan pengguna sistem dalam penggunaan teknologi informasi menjadi penting sebagai faktor penentu pada setiap orang yang menjalankan teknologi informasi. Pengguna sistem adalah man yang secara psikologi memiliki suatu 
behavior tertentu yang melekat pada dirinya sendiri. ${ }^{16}$

Selain kelayakan teknis dilihat juga dari segi kelayakan ekonomi hal ini untuk mengetahui apakah terdapat anggaran dan dapat memberikan manfaat bagi Dinas Kesehatan maupun Puskesmas. Analisis kelayakan ekonomi dilakukan untuk memperkirakan biaya dan keuntungan dalam membangun sistem informasi. ${ }^{10}$ dari hasil wawancara bahwa untuk anggaran pemeliharaan dan evaluasi sistem terdapat di Dinas Kesehatan dan biasa dilakukan triwulan pada saat kegiatan validasi data.

\section{Analisis Masalah}

Pada tahapan analisis masalah dapat diidentifikasi kendala-kendala dan hambatan yang dialami pada saat input, proses dan output dari sistem yang sudah berjalan.

Dari hasil rangkuman pada analisis permasalahan dapat ditelusuri penyebab timbulnya permasalahan dan solusi yang diusulkan. Ada beberapa permasalahan dan solusi yang diusulkan

a. Kesulitan akses data dan informasi solusi yang diusulkan adalah dengan mengembangkan sistem informasi yang terkomputerisasi dengan menggunakan manajemen basis data sehingga memudahkan mengakses data dan informasi.

b. Ketidaklengkapan data dan informasi solusi yang diusulkan berupa pengembangan sistem yang mencakup data dan laporan secara keseluruhan program imunisasi secara lengkap. Penyajian output dalam bentuk grafik dan pemetaan untuk analisis evaluasi program imunisasi sampai tingkat desa.

c. Ketidaktepatan waktu pelaporan Bentuk pengembangan sistem yang real time dengan berbasis website sehingga pelaporan bisa tepat waktu.

\section{Analisis Kebutuhan}

Dari hasil wawancara dan pengamatan didapatkan bahwa prosedur yang sudah ada dianalisis dan didiskusikan dan diperoleh hasil sebagai berikut :

1) Sistem informasi menghasilkan informasi yang visual sesuai kebutuhan di tingkat pengguna dalam hal penyajian data.

2) Sistem informasi yang dikembangkan juga harus memudahkan pengguna dalam pengoperasiannya.

3) Sistem informasi imunisasi yang akan dikembangkan harus dapat memperbaiki manajemen data khususnya pada rekap kegiatan imunisasi sehingga menghasilkan informasi yang berkualitas baik dari segi kelengkapan, kemudahan, kesesuaian, dan ketepatan waktu.

\section{Analisis Keputusan}

Tahap analisis keputusan bertujuan untuk mengidentifikasi dan menganalisis alternatif solusi pada sistem yang akan dikembangkan. Hasil yang didapat dari wawancara mendalam adalah bahwa pada penentuan model pengembangan sistem informasi menggunakan pendekatan Top Down yang menganalisis kebutuhan informasi dimulai dari level manajemen atas yang kemudian dilanjutkan ke proses alur pencatatan yaitu penentuan input, output, basis data, prosedur-prosedur operasi dan kontrol. Hal ini merupakan ciri pendekatan terstruktur karena yang diutamakan adalah kebutuhan informasi untuk pengambilan keputusan terlebih dahulu baru kemudian data apa saja sebagai inputannya yang perlu diolah dan dianalisis mengikuti informasi yang dibutuhkan. ${ }^{17}$

Penentuan sistem operasi yang digunakan adalah Microsoft Windows 
karena sistem operasi tersebut banyak digunakan di perkantoran dan pemrograman menggunakan PHP sangat cocok dengan sistem operasi MS Windows. Software yang digunakan dalam penelitian ini menggunakan bahasa pemrograman PHP. PHP merupakan bahasa pemrograman berbasis web dengan menggunakan server. Sedangkan untuk basis datanya menggunakan MySQL. MySQL merupakan sebuah perangkat lunak sistem manajemen basis data SQL atau DBMS (Database Manajemen system).

\section{Tahap Perancangan Sistem}

Tahap ini merupakan analisis untuk merancang sistem informasi untuk mendukung evaluasi program imunisasi di Dinas Kesehatan Kabupaten Brebes. Tujuan pengembangan sistem ini untuk mendukung evaluasi program imunisasi sehingga dapat menghasilkan informasi secara lengkap, mudah, sesuai dan tepat waktu. Hasil perancangan yang dilakukan dalam penelitian ini menggunakan langkahlangkah sebagai berikut :

\section{a) Diagram Konteks}

Diagram konteks merupakan diagram awal dari sistem informasi yang menggambarkan aliran-aliran data ke dalam dan keluar entitasentitas eksternal.

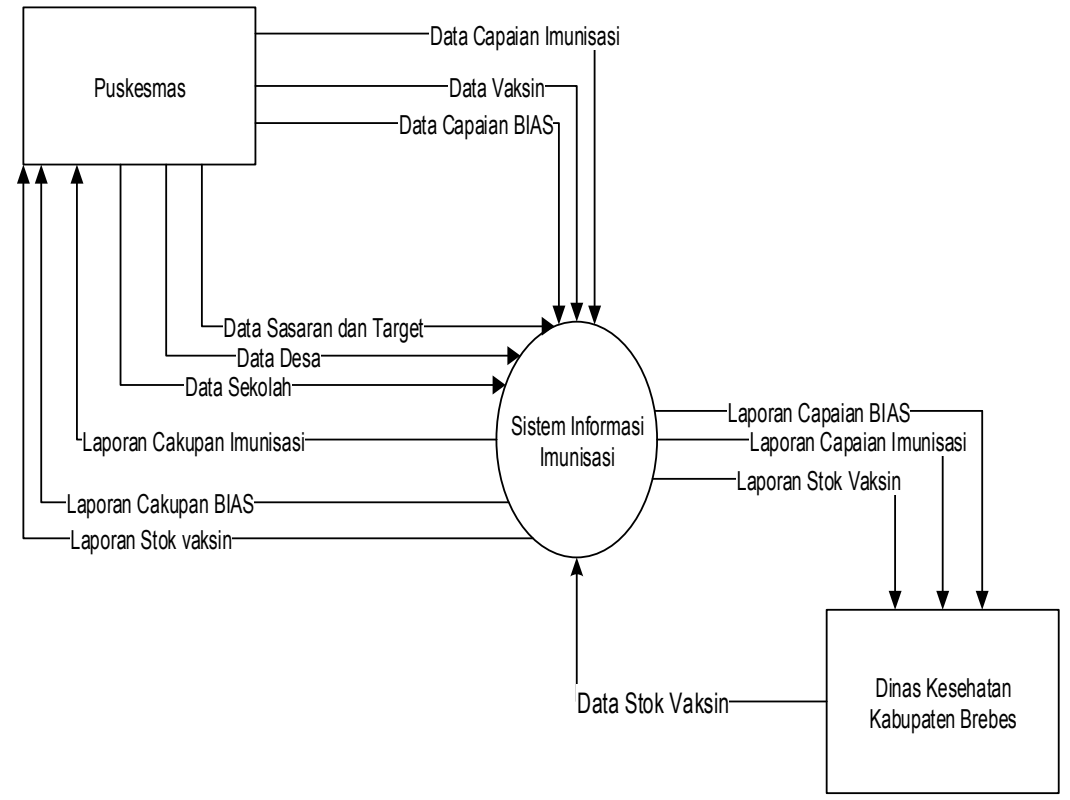

Gambar 1. Diagram Konteks Sistem Informasi Imunisasi

\section{b) Diagram Alir Data (DAD)}

Turunan dari diagram konteks adalah Diagram Alir Data yang dapat menggambarkan secara rinci dan lebih jelas proses aliran data yang terdapat dalam sistem informasi. DAD merupakan perangkat analisis untuk menggambarkan fungsi sistem yang berhubungan satu dengan yang lain sesuai aliran dan penyimpanan data.
Adapun tujuan dari DAD adalah untuk mendefinisikan proses apa saja yang terdapat dalam sistem yang akan dibangun.

Berikut rangkuman proses pada sistem informasi imunisasi yaitu :

1) Input

Pada proses input ini, yang memasukkan data ke dalam sistem informasi dilakukan oleh petugas 
pengolah data imunisasi di Puskesmas. Data yang dimasukkan meliputi data pelayanan imunisasi menurut kategori sasaran Bayi (0 11 bulan), Batita, Balita Umur 12 23 bulan, Balita Umur 24-35 bulan, Wanita Hamil dan Wanita tidak hamil, pelayanan imunisasi di sekolah dan stok vaksin yang ada di Puskesmas. Untuk stok vaksin yang ada di Dinas Kesehatan diinput oleh petugas pengolah data imunisasi di Seksi surveilans dan imunisasi.

2) Proses

Proses atau transaksi adalah kegiatan mengolah data input berupa menjumlah, merekap, presentasi, dan lain - lain yang menghasilkan output berupa laporan cakupan imunisasi, BIAS dan stok vaksin.

\section{3) Output}

Output adalah hasil dari proses yang pada sistem ini menyediakan output dalam bentuk tabel, grafik maupun pemetaan untuk informasi cakupan imunisasi. Dan output dalam bentuk tabel saja untuk cakupan imunisasi BIAS dan stok vaksin.

\section{c) Rancangan input dan Output}

Rancangan input bertujuan untuk memberikan bentuk-bentuk masukan di dokumen dan di layer ke sistem informasi. Input merupakan langkah dimulainya proses informasi. Pada rancangan input disesuaikan dengan form pencatatan yang ada sehingga kebutuhan dari data dapat terpenuhi. Pada dasarnya desain input terdiri dari dua tahapan yaitu : penangkapan data menggunakan dokumen dasar sehingga proses ini memerlukan perancangan form dan pemasukan data ke dalam komputer sehingga pada proses ini memerlukan perancangan antar muka atau interface. ${ }^{18}$

Hasil perancangan input pada sistem informasi imunisasi meliputi rancangan input data pelayanan imunisasi, data palayanan BIAS dan data stok vaksin.

\section{Tahap Pembangunan Sistem}

Tahap dalam pembangunan sistem merupakan tahap yang bertujuan menerjemahkan hasil rancangan ke dalam program komputer sesuai dengan sumber daya yang tersedia (Hardware dan Software). Tahapan ini juga akan menentukan aliran data yang perlu dikembangkan dan mengimplementasikan interface sistem yang diusulkan.

Berikut adalah contoh bentuk tampilan layar yang telah dicapture dari sistem.

a. Tampilan halaman login

Halaman login digunakan untuk membatasi hak akses penggunanya dalam hal melakukan pengoperasian sistem untuk mendukung keamanan data dan informasi dari pengakses yang tidak diinginkan.

b. Tampilan menu utama

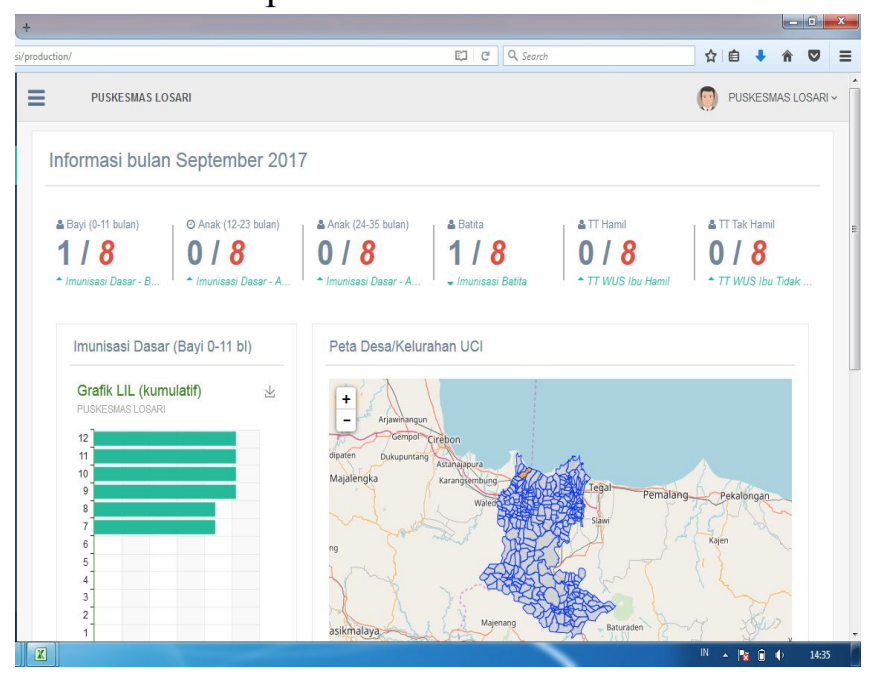

Gambar 3. Tampilan menu utama

Tampilan yang akan muncul setelah login dengan memasukkan username dan password untuk level puskesmas maka akan muncul tampilan utama menyajikan menu data input, 
laporan, grafik, pemetaan, setting data dan $\log$ out. Menu tampilan ini digunakan sebagai alat untuk masuk menu yang diinginkan pengguna.

\section{c. Tampilan menu input}

Tampilan menu input terdiri dari rekap data desa yang terdiri dari capaian imunisasi, capaian BIAS dan Data Vaksin. Tampilan input capaian imunisasi meliputi imunisasi dasar bayi (0-11 bulan), imunisasi dasar anak (1223 bulan), capaian imunisasi batita, capaian imunisasi anak (23-35 bulan), capaian imunisasi wanita tidak hamil, capaian imunisasi wanita hamil. Inpu capaian BIAS meliputi capaian imunisasi campak, DT (Difteri Tetanus) dan Td (Tetanus difteri).

d. Tampilan menu laporan

Menu laporan digunakan untuk menampilkan laporan dalam bentuk tabel yang dibutuhkan di puskesmas dan kabupaten. Laporan dalam bentuk tabel meliputi imunisasi dasar bayi (011 bulan), imunisasi dasar anak (12-23 bulan), capaian imunisasi batita, capaian imunisasi anak (23-35 bulan), capaian imunisasi wanita tidak hamil, capaian imunisasi wanita hamil, laporan UCI, laporan BIAS, laporan data stok vaksin.

\section{e. Tampilan menu grafik}

Tampilan menu grafik digunakan untuk menampilkan grafik capaian imunisasi, grafik capaian UCI, grafik DO DPTHB-Hib 1-3, DO DPTHBHib-Campak, dan grafik cakupan imunisasi bayi dan batita.

\section{f. Tampilan menu pemetaan}

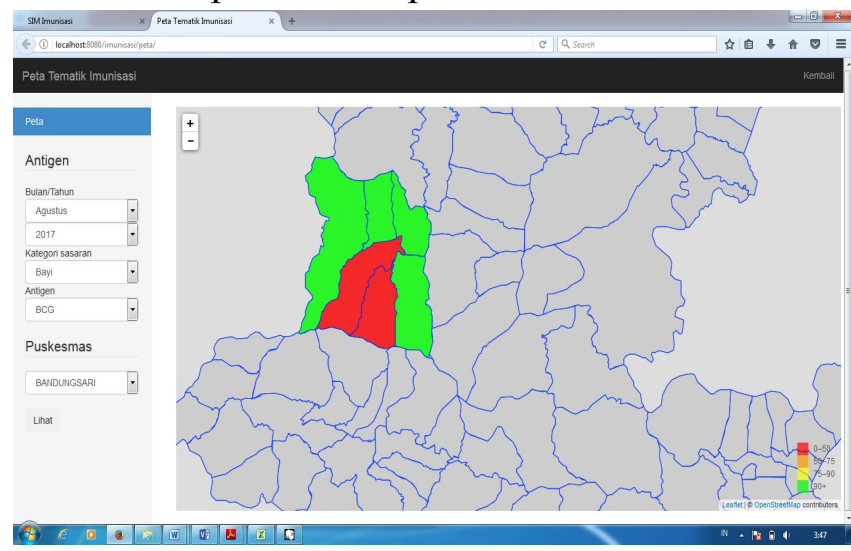

Gambar 7. Tampilan menu pemetaan

Gambar ini digunakan untuk melihat cakupan imunisasi sampai ke titik desa. Sehingga dapat diketahui desa mana saja yang belum memenuhi target dilihat dari label pewarnaannya.

\section{Tahap Penerapan/Ujicoba Sistem}

Tahapan selanjutnya dalam pengembangan sistem yaitu penerapan sistem. Tujuan uji coba dari sistem informasi imunisasi adalah untuk memastikan apakah sistem informasi sudah sesuai dengan kebutuhan dan sesuai dengan harapan yang diinginkan oleh pengguna.

Ujicoba sistem ini dilakukan di Dinas Kesehatan Kabupaten Brebes secara serentak dengan mengundang 20 puskesmas sebagai sampel penelitian ujicoba. Tiap puskesmas mengirimkan 1 (satu) orang petugas pengelola data imunisasi.

\section{Tahap Evaluasi Sistem}

Prinsip utama yang dijadikan ukuran keberhasilan pengembangan sistem informasi (SI) ataupun perangkat lunak (PL) adalah usability. Tingkat usability menentukan apakah sistem tersebut akan bermanfaat, diterima user dan bertahan lama dalam penggunaannya.

Pada penelitian ini untuk mengukur keberhasilan pengembangan sistem dengan menggunakan paket kuesioner PSSUQ (Post Study System Usability Quesionnaire) 
yang dapat digunakan untuk mengukur usability $^{13,14}$

Perhitungan skor yang diperoleh dari masing-masing pertanyaan adalah untuk hasil skor system usefullnes yang menghasilkan 65,09\%, information quality hasil skor yang didapatkan adalah $71,12 \%$, interface quality mendapatkan skor 71,67\% yang berdasarkan tabel 1 . penyesuaian Likert termasuk kategori "Layak". Kemudian pada pengukuran secara keseluruhan overall satisfaction menghasilkan skor $69,06 \%$ hal ini menunjukkan bahwa sistem informasi imunisasi termasuk kategori "Layak".

\section{KESIMPULAN DAN SARAN}

Sistem pengumpulan data imunisasi terpadu yang dikembangkan untuk kebutuhan evaluasi program berupa sistem pencatatan yang meliputi cakupan imunisasi rutin, cakupan BIAS dan distribusi vaksin. Sistem ini juga dikembangkan berbasis sistem informasi geografis sehingga output yang dihasilkan terdapat pemetaan cakupan imunisasi sampai tingkat desa. Hasil evaluasi sistem menunjukkan bahwa sistem yang telah dikembangkan memiliki kategori "Layak" untuk digunakan. Untuk keberlangsungan sistem perlu dibuat kebijakan tentang pemanfaatan sistem serta pelatihan terhadap pengguna sistem di seluruh Puskesmas wilayah kerja Dinas Kesehatan Kabupaten Brebes.

Keterbatasan penelitian ini mencakup tidak menyediakan fasilitas perhitungan indeks pemakaian vaksin serta evaluasi hanya dilakukan pada saat implementasi sistem dengan mengukur tingkat usability saja tidak sampai mengukur tingkat kinerja dan manajemen sebagai efek dari pengembangan sistem.

\section{UCAPAN TERIMA KASIH}

Terima kasih saya ucapkan kepada Kepala Dinas Kesehatan Kabupaten Brebes, Kepala Bagian Bidang Pencegahan dan Pengendalian Penyakit, Kepala Seksi Surveilans dan Imunisasi serta seluruh responden staf imunisasi Puskesmas wilayah Dinas Kesehatan Brebes yang telah mendukung dan mengijinkan terlaksananya penelitian ini.

\section{DAFTAR PUSTAKA}

1. Peraturan Menteri Kesehatan No.42 Tahun 2013 Tentang Penyelenggaraan imunisasi

2. Corry, S.M. Aspek Imunologi Imunisasi, Buku Imunisasi di Indonesia, Edisi Pertama, Satgas Imunisasi IDAI; 2001.

3. Profil Kesehatan Kabupaten Brebes 2017. Badan Pusat Statistik Kabupaten Brebes; 2017.

4. Has S.D.F, N.Basuki.H, W.Umbul. C. Pengembangan Sistem Informasi Surveilans Imunisasi dan PD3I di Dinas Kesehatan Kota Surabaya. Jurnal Wiyata. 2016; 3(1): 67-75.

5. Wilis Kaswidjanti, Budi Santosa, rifky Satya Wicaksono. Sistem Informasi Geografis Pemetaan Fasilitas Kesehatan di Kota Magelang Berbasis $W e b$. Seminar Nasional Informatika 2008 "UPN Veteran"Yogyakarta, 24 Mei 2008

6. Direktorat Jenderal Pengendalian Penyakit dan Penyehatan Lingkungan, Kementerian Kesehatan RI. Modul Pelatihan Imunisasi Bagi Petugas Puskesmas. Tahun 2013.

7. Kementerian Kesehatan RI. Peraturan Menteri Kesehatan No.97 Tahun 2015 tentang Peta Jalan Sistem Informasi Kesehatan. Jakarta: Kemenkes RI; 2015. 
8. Isnawati K, Nugroho E, Lazuardi L. Implementasi Apilkasi Sistem Informasi Kesehatan Daerah (SIKDA) Generik di UPT. Puskesmas Gambut Kabupaten Banjar. Journal of Information Systems for Public Health. April 2016; 1(1): $64-71$.

9. Jogiyanto, HM, Analisis \& Desain Sistem Informasi Pendekatan Terstruktur Teori dan Praktek Aplikasi Bisnis. Yogyakarta: Andi; 2005.

10. Whitten, JL. Metode Desain \& Analisa Sistem. Edisi 6. Yogyakarta: Penerbit Andi; 2004.

11. Sutejo, B. Perencanaan dan Pembangunan Sistem Informasi. CV. Andi, Yogyakarta, 2002.

12. Sauro, J, “ 8 Advantages of Standardized UsabilityQuestionnairres", diaksesdarihttp//www.measuringusabilit y.com/blog/standardizedusability.php, tanggal 10 Februari 2017.

13. Zahro Siti, Lazuardi Lutfan, Utarini Adi. Evaluasi prototipe sistem pencatatan dan pelaporan insiden keselamatan pasien (IKP) berbasis web di Rumah Sakit. Program S2 IKM. Universitas Gajah Mada.
14. Nielsen, Jakob, Usability 101 : Introduction. Diakses dari https://www.nngroup.com/articles/usabi lity-101-introduction-to-usability/ tanggal 10 Februari 2017.

15. Riduwan. Belajar Mudah Penelitian untuk Guru-Karyawan dan Peneliti Pemula. Bandung: Penerbit Alfabeta; 2011

16. Lindawati, $\mathrm{Hj}, \quad$ Salamah Irma. Pemanfaatan Sistem Informasi Dan Teknologi Informasi Pengaruhnya Terhadap Kinerja Individual Karyawan. Jurnal Akuntansi Dan Keuangan, Vol. 14, No. 1, Mei 2012: 56-68. Politeknik Negeri Sriwijaya.

17. Kumorotomo, Wahyudi. Sistem Informasi Manajemen Dalam Organisasi Organisasi Publik. Yogyakarta: Gajah Mada University Press; 2004.

18. Cresswell, K., \& Sheikh, A. Organizational Issues In The Implementation And Adoption Of Health Information Technology Innovations: An Interpretative Review. International Journal of Medical Informatics, 82(5), e73-86. 